\title{
Effect of Edge Trimming Parameters on Surface Quality of Carbon Fiber Reinforced Polymer Composites
}

\section{Ahmet Can}

Necmettin Erbakan Üniversitesi, Mühendislik Fakültesi, Endüstriyel Tasarım Bölümü, Köyceğiz- Meram/KONYA

e-posta: ahmetcan@konya.edu.tr

Geliş Tarihi: 13.10.2016; Kabul Tarihi:04.04.2017

Keywords

CFRP, Edge Trimming,

Delamination, Taguchi,

ANOVA, Surface

Roughness

\begin{abstract}
The main focus of this paper is to investigate the surface quality and machinability of the edge trimming process of carbon fiber reinforced polymer (CFRP) material. Measurement of transverse and longitudinal surface roughness and deformation behavior are carried out for different combinations of cutting speed, feed per tooth, tool type and milling type to evaluate the machined surface quality. Three different flutes $(2,4,6)$ micro grain carbide end mill tools were used for vertical and inclined peripheral milling. Edge trimming experiments were conducted under different experimental parameters and their levels according to the Taguchi design of experiment method. The contribution ratio of parameters on machinability outputs has statistically analyzed by Analysis of Variance (ANOVA) According to machinability outputs such as surface roughness and deformation types, the inclined peripheral milling is more suitable than vertical peripheral milling. Edge trimming by vertical peripheral milling generates Type II delamination which consists of long uncut fibers protruding from the trimmed edges. Edge trimming by inclined milling generates Type I-II delamination which consists of short uncut fibers protruding from the trimmed edges and where plies have broken inwards in the same time. The transverse and longitudinal surface roughness and deformation decreased with increased number of teeth, cutting speed and decreased feed per tooth. The best machining quality was obtained when cutting at the highest level of cutting speed, lowest feed rate and 6 number of flute in inclined milling.
\end{abstract}

\section{Karbon Fiber Takviyeli Polimer Kompozitlerin Kenar Budama Değişkenlerinin Yüzey Kalitesine Etkisi}

\section{Özet}

Bu çalışmada karbon elyaf takviyeli polimer matrisli kompozitlerin kenar budama işlemlerinin işlenebilirliği ve yüzey kalitesi araştırıımıştır. Frezeleme tipi, takım tipi, kesme hızı ve ilerleme hızının, yüzeyin ilerleme ve ilerlemeye dik doğrultusunda oluşan yüzey pürüzlülüğüne ve deformasyon davranışına olan etkileri araştırıımıştır. Üç farklı kesici ağız sayısına $(2,4,6)$ sahip mikro taneli karbür kesici takımlarla dik ve eğimli çevresel frezeleme işlemi gerçekleştirilmiştir. Kenar budama işlemleri için kullanılan frezeleme parametreleri Taguchi deney tasarımına göre uyarlanmıştır. Parametrelerin işlenebilirlik çıktıları üzerine etkilerinin katkı oranları varyans analizi (ANOVA) ile istatistiksel olarak belirlenmiştir. İşlenebilirlik çıktıları olan yüzey pürüzlülüğü ve deformasyon miktarlarına göre eğimli yanal frezeleme işleminin dik frezelemeye göre daha üstün olduğu sonucuna varılmıştır. Dik yan yüzey frezelemeyle yapılan kenar budama işlemlerinde Tip-II delaminasyon yani kenarlarda kesilmeden uzayan uzun elyaf demetlerinin bulunduğu gözlenmektedir. Eğimli frezeleme ise Tip I-Il delaminasyonun aynı anda ortaya çıkarmakta yani kenarlarda kesilmemiş uzun elyaf demetleri ve kenardan içe doğru kırılmış tabakalar oluşturmaktadır. Kesici ağız sayısı ve kesme hızı arttıkça ve ilerleme hızı azaldıkça enine ve boyuna olan yüzey pürüzlülüğü ile deformasyon azalmaktadır. En iyi işleme koşulları kesme hızının en yüksek seviyede, ilerlemenin en düşük seviyede 6 ağızlı kesicide eğimli frezeleme koşullarında sağlanmıştır.

(c) Afyon Kocatepe Üniversitesi 


\section{Introduction}

Polymer matrix composites such as glass and carbon fiber reinforced composites are important class of materials in advanced structural applications such as aerospace, aircraft, automobile and sport goods due to their lightweight, highly modulus and highly specific strength. Components made from composite materials are normally cured to near-net-shape by using various shaping technique with die-molds. While molding, the desired gaps like bolt-rivet holes ignored. After molding the edges of the composite parts are generally serrated and longer than design dimensions. The gaps like holes, the sharp edges and dimensional tolerances must be obtained by additional machining operations such as drilling, grinding, milling, edge trimming etc. in composite parts. However, because of their anisotropic, heterogeneous and brittle nature, these materials are difficult to machine by comparing to traditional isotropic materials (Faraz et. al 2009, Haddad et al. 2014).

In aerospace and automobile parts bolt-rivet joining effectiveness and part strength depends critically on the quality of the edges. The micro cracks and deformation near the hole makes a stress concentration and crack propagation on edges. And it may cause the premature static and fatigue failure near the bolts and rivets. The quality of machined holes in Fiber Reinforced Polymer) FRP is strongly depending on the appropriate choice of the cutting parameters for the structure of the composite material (Azmi et al. 2013, Rajamurugan et al. 2013, Paulo and Dawim 2005).

The previous works about machining of composites indicated that the parameters such as cutting speed, feed rate, tool material, tool geometry, fiber orientations and rake angles and type of machining such as high speed milling have a great effect on the quality of the machine surface. It is essential to highlight here that due to the actions of machining forces, FRP composites exhibit a number of material damage or machining induced damage, which would not be normally observed during machining of metallic material. These types of damage include delamination, sub-surface damage, fiber pull out, fiber bridging, spalling, and matrix cracking (Tsao 2008, Tsao and Chiu 2001, Bhanacar et al. 1995, Ramulua et al. 2003).

The service life of composite components is believed to be highly dependent on machining quality and damage due to machining may result in scraping expensive parts. Some of the researcher focused the effect of the machining type and parameters on mechanical behavior of the composite material. The defects generated by different machining processes (namely burr tool machining, abrasive water jet machining and abrasive diamond cutter) and their impact on the mechanical behavior of CFRP in quasi-static (compression and inter-laminar shear) and tensile tensile fatigue tests were realized. The defects while machining is related to surface roughness and mechanical behavior (Haddad et al. 2014).

In this context, Jamal Sheikh Ahmad et al. found that transverse surface roughness does not have clear trends and is generally higher than the longitudinal surface roughness. They added that surface roughness in the longitudinal direction increased with an increase in feed rate and a decrease in spindle speed (Ahmad Et al. 2012)

The previous works of a number of authors have shown that cutting parameters radically influence the surface quality. The edge delamination damage mechanisms and surface roughness have a great effect on surface quality and fatigue life of the components. Especially, the aerospace components which are working by cyclic loads affected from delamination. This delamination can be eliminated by manual deburring operation with human hand. These deburring operations are hazardous and increase the cost of the products. The present work is focused on the tool geometry, cutting parameter and milling type (vertical and inclined) for obtaining a net shape or quality surface which does not require extra deburring operations. It is the first work about applying the inclined milling to composite machining. In real world industrial applications especially in aerospace and automotive industry edge trimming operations are made by multi axis milling robots. The multi axis robots have higher degrees of freedom and they can achieve easily to desired inclined machining angles by comparing the milling 
centers. So the inclined milling can be realized easily by multi axis robots.

\section{Material and Methods}

The composite materials used in tests includes continuous unidirectional $\left(195 \mathrm{gr} / \mathrm{m}^{\wedge} 2\right)$ tape and plain weave $\left(450 \mathrm{gr} / \mathrm{m}^{\wedge} 2\right)$ fabric carbon fiber reinforced layers with $40 \%$ of epoxy matrix. The 10 $\mathrm{mm}$ thickness composite plates were produced by 40 layer prepregs $(0.25 \mathrm{~mm}$ thick) with different fiber orientations $\left(0-90-45-135^{\circ}\right)$. The upper layer includes $2 \mathrm{~mm} 45-135^{\circ}$ plain weave fiber orientations. The layers and fiber orientation details were depicted in Fig.1 (a). The parts were made by manual lay-up then vacuum bag was applied. The parts were cured at $180{ }^{\circ} \mathrm{C}$ under 6 bar external pressure.

The milling experiments were performed on a SunMill CNC machining center under dry conditions. The transverse (Ra-T) and longitudinal arithmetic average of the surface roughness (Ra-L) was measured with Yamer Surftest PST 210 along the tool axis and feed direction. The average roughness, Ra was used to characterize the surface quality. For determining the effect of inclined and vertical milling all the edge trimming experiment performed with parallel and inclined part position with up (conventional) milling. The parameters, directions of roughness (Ra-T,Ra-L), vertical and inclined milling details were depicted in Fig.1(a)

The flute space is an important tool geometry parameter which effects of chip carrying capacity. The lower number of flutes such as two flute end mill has the greatest amount of flute space allowing for more chip carrying capacity. The slotting and pocketing applications of non-ferrous materials where chip removal is a concern can be done with these tools. The three flute tool has the nearly same flute space as two-flutes and it has a larger cross sectional area providing for greater strength and the ability to pocket and slot both ferrous and non-ferrous materials. The multiple flutes such as 4-6-8-fluted tools are suitable for peripheral and finish milling. The higher flute numbers allow faster feed rates which are the most effective parameter on machining time. But higher number of fluted-tool geometry causes a chip removal problem due to the reduced flute space.
The three different tools that used in the experiments were depicted in Fig. 1(b).

\subsection{Experimental Procedure and DOE}

Taguchi Design of Experiment (DoE) Methodology is a very efficient and economical way of experimental design that drastically reduces the number of required experiments (Sarıkaya 2015). Three different uncoated tungsten carbide end milling tools of $8 \mathrm{~mm}$ diameter and 2-4-6 helical flute were used. Three important machining parameters, namely feed rate, (f) cutting speed, (V) and flute number $(T)$, were selected with three levels for this study. Each experiment was repeated 3 times and all the output value is averaged. In the classical full factorial experimentation, for one repeating procedure ( 3 levels ${ }^{\wedge} 3$ factor) $3^{\wedge} 3=27$ tests would be needed to complete the entire experimental work. Based on the selected levels and parameters, this study can be performed using the L9 Taguchi Orthogonal Array (OA) in which 9 tests would be required to complete the array.

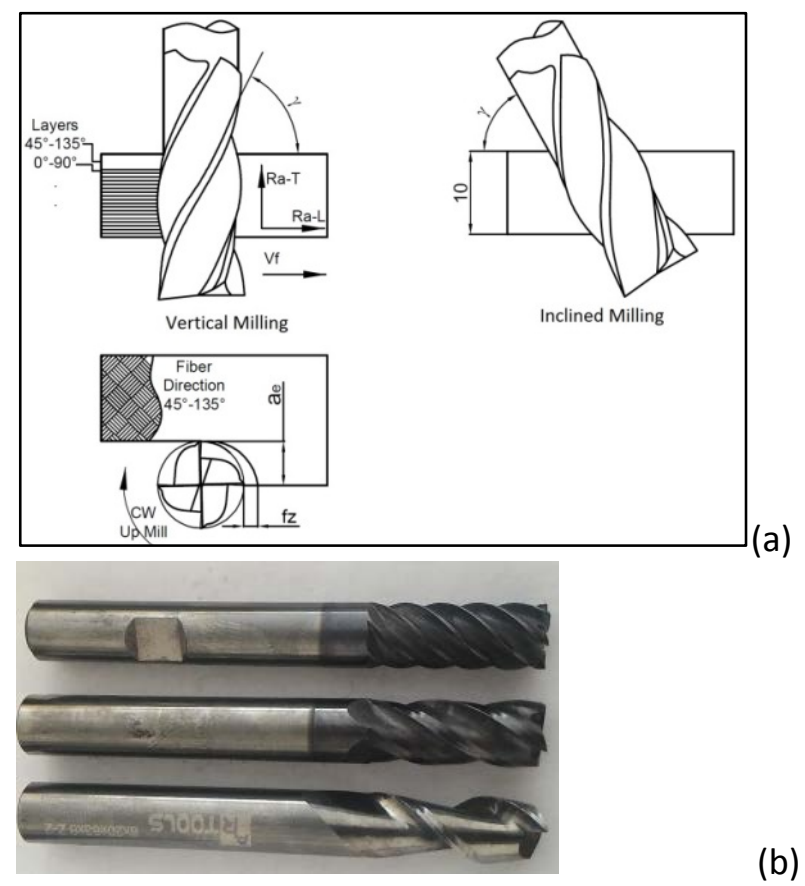

Figure 1. Vertical and inclined milling details. 2-4-6 flute End-Mill Tools Used in The Experiments

Three levels of three cutting parameters Cutting Speed, Feed Rate and Flute Number) that used in the experiments were depicted in Table 1. All machinability outputs were analyzed by using the 
lower the better signal-to-noise $(\mathrm{S} / \mathrm{N})$ ratio. The $\gamma$ indicates the milling inclination angles and it was adjusted as $45-55^{\circ}$ in the experiment. The radial depth of cut $a_{e}$ was adjusted $1 \mathrm{~mm}$ in the experiments.

$$
\frac{s}{N}=-10 \log \frac{1}{n}\left(\sum y^{2}\right)
$$

Table 1. Taguchi DoE and Experimental Parameters

\begin{tabular}{ccccccc}
\hline NO & $\begin{array}{c}\text { A } \\
\text { (T) }\end{array}$ & $\begin{array}{c}\text { B } \\
\text { (V) }\end{array}$ & $\begin{array}{c}\text { C } \\
\text { (fz) }\end{array}$ & $\begin{array}{c}\text { Number } \\
\text { of Flute } \\
\text { (T-teeth) }\end{array}$ & $\begin{array}{c}\text { Cutting } \\
\text { Speed } \\
\mathbf{V} \\
(\mathbf{m} / \mathbf{m i n})\end{array}$ & $\begin{array}{c}\text { Feed } \\
\mathbf{f z} \\
(\mathbf{m m} / \text { teeth) }\end{array}$ \\
\hline 1 & 1 & 1 & 2 & 50 & 0.05 \\
1 & 2 & 2 & 2 & 100 & 0.1 \\
1 & 3 & 3 & 2 & 150 & 0.15 \\
2 & 1 & 2 & 4 & 50 & 0.1 \\
2 & 2 & 3 & 4 & 100 & 0.15 \\
2 & 3 & 1 & 4 & 150 & 0.05 \\
3 & 1 & 3 & 6 & 50 & 0.15 \\
3 & 2 & 1 & 6 & 100 & 0.05 \\
3 & 3 & 2 & 6 & 150 & 0.1 \\
\hline
\end{tabular}

\section{Results and Discussion}

\subsection{Surface roughness analysis}

The transverse (Ra-T) and longitudinal (Ra-L) arithmetic average of the surface roughness was measured from machined surface as depicted Fig. 1(a). Ahmad et al. reported that the surface roughness along the tool and feed axis are affected from cutting parameters differently from each other. The transverse (Ra-T) arithmetic average of the surface roughness is measured along tool axis, the longitudinal arithmetic average of the surface roughness is measured along the tool movement on surface. The arithmetic average of the surface roughness for inclined and vertical milling is depicted with subscript "i"," v" as Ra-Li, Ra-Lv, Ra$\mathrm{Ti}, \mathrm{Ra}-\mathrm{TV}$. Table 2 shows the response table and ANOVA results for calculated $S / N$ ratios of arithmetic average of the surface roughness for vertical milling along the longitudinal direction (RaLv). It can be derived from the Table 2 and Main effects plots (Fig. 2) that the greater influence on the arithmetic average of the surface roughness is feed rate followed by cutting speed and Tool type (teeth number).

As depicted in surface plots Fig. $3(a, b)$ the minimum longitudinal arithmetic average of the surface roughness was achieved from 2 and 6 number of flute tool with minimum feed rate ( $\mathrm{f}=0.05 \mathrm{~mm} /$ teeth).

Table 2 Response and Anova Table for Ra-Lv

\begin{tabular}{lllll}
\hline Level & $\mathbf{T}$ & $\mathbf{V}$ & $\mathbf{f z}$ & $\begin{array}{l}\text { Error / } \\
\text { Total }\end{array}$ \\
\hline $\mathbf{1}$ & $-3.380^{*}$ & -5.823 & $-1.239 *$ & \\
$\mathbf{2}$ & -6.308 & -5.389 & -5.520 & \\
$\mathbf{3}$ & -3.737 & $-2.214^{*}$ & -6.667 & \\
Delta & 2.928 & 3.609 & 5.428 & \\
Rank & 3 & 2 & 1 & \\
DF & 2 & 2 & 2 & $2 / 8$ \\
Seq SS & 1.36 & 1.04 & 1.88 & $0.4 / 4.71$ \\
MS & 0.68 & 0.52 & 0.94 & 0.2 \\
F-Value & 3.27 & 2.52 & 4.54 & \\
PCR\% & 28.85 & 22.25 & 40.06 & \\
R^2 =91.2\% & $*:$ Optimum parameter level \\
\hline
\end{tabular}

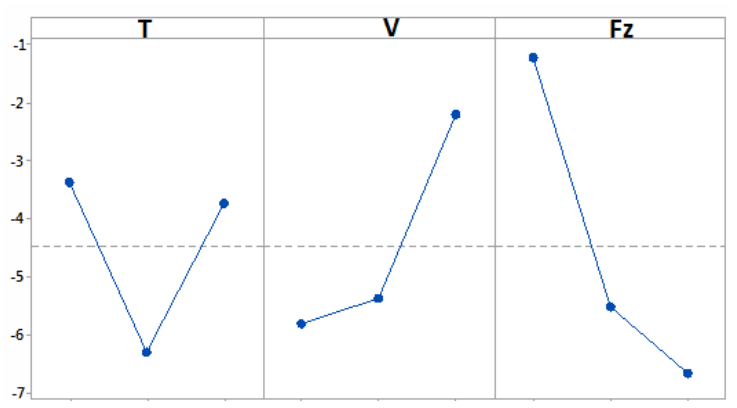

Figure 2. Main effect plot of Ra-Lv against T-V-fz.

The increased arithmetic average of the surface roughness in the 4 flute tool can be explained by a chip removal problem with closed flute space. It was clearly shown in Table 2 and in Fig. 3(a), the suitable machining parameters for minimum arithmetic average of the surface roughness can be obtained with number of flute Level 1 (2 Flute), cutting speed at Level $3(\mathrm{~V}=150)$ and feed rate $(\mathrm{f})$ at Level $1(f=0.05)$. This experiment level (131) has not realized in the planned orthogonal array (Table 1) and this result can be estimated by Eq.2 and back transform of Eq1. or can be determined by confirmation experiment. The result of estimation and confirmation experiment detailed in future section. As it can be seen from the Anova Table of $\mathrm{S} / \mathrm{N}$-Ra the feed per tooth is the major factor 
(40.6\%) affecting on the arithmetic average of the surface roughness.

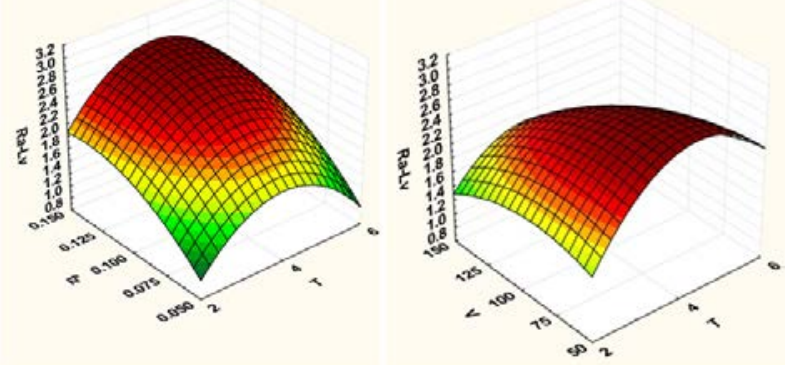

Figure 3. Surface plot of Ra-Lv against T-fz and T-V.

Table 3 shows the response table, main effects plots and Anova results for calculated $\mathrm{S} / \mathrm{N}$ ratios of arithmetic average surface roughness for inclined milling along the longitudinal direction (Ra-Li). It can be derived from the Table 3 and Main effects plots (Fig. 4) that the greater influence on the longitudinal arithmetic average of the surface roughness is feed rate followed by Tool type (teeth number) and cutting speed. The arithmetic average of the surface roughness values in inclined milling (Ra-Li) are lower than vertical milling in almost in all cases.

As depicted in surface plots Fig. $5(a, b)$ the minimum longitudinal arithmetic average of the surface roughness was achieved from 2 number of flute tool with minimum feed rate $(f=0.05$ $\mathrm{mm} /$ teeth). It was clearly shown in Table 3 and in Fig. 5 (a), the suitable machining parameters for minimum arithmetic average of the surface roughness are Number of flute Level 1 (2 Flute), cutting speed at Level $2(V=100)$ and feed rate $(f)$ at Level $1(f=0.05)$. This experiment Level (121) has not realized and it will be realized by confirmation experiment. As it can be seen from the Anova Table of $\mathrm{S} / \mathrm{N}-\mathrm{Ra}$ the feed per tooth is the major factor $(72.6 \%)$ affecting on the arithmetic average of the surface roughness.

Table 4 shows the response table, main effects plots and Anova results for calculated $\mathrm{S} / \mathrm{N}$ ratios of arithmetic average of the surface roughness for vertical milling along the transverse direction (RaTv). It can be derived from the Table 4 and main effects plots (Fig. 6) that the greater influence on the transverse arithmetic average of the surface roughness is feed rate followed by tool type (teeth number) and cutting speed.

Table 3. Response and Anova Table for Ra-Li

\begin{tabular}{lcccc}
\hline \multicolumn{1}{c}{ Level } & $\mathbf{T}$ & $\mathbf{V}$ & $\mathbf{f z}$ & $\begin{array}{c}\text { Error / } \\
\text { Total }\end{array}$ \\
\hline $\mathbf{1}$ & $1.06^{*}$ & -0.97 & $2.45^{*}$ & \\
$\mathbf{2}$ & -0.79 & $0.32^{*}$ & -0.67 & \\
$\mathbf{3}$ & -0.90 & 0.015 & -2.41 & \\
Delta & 1.90 & 1.29 & 4.86 & \\
Rank & 2 & 3 & 1 & \\
DF & 2 & 2 & 2 & $2 / 8$ \\
Seq SS & 0.117 & 0.069 & 0.508 & $0.005 / 0.7$ \\
MS & 0.058 & 0.034 & 0.254 & 0.0027 \\
F-Value & 21.65 & 12.78 & 93.88 & \\
PCR\% & 16.74 & 9.88 & 72.6 & \\
R^2 = 99.2\% & *: Optimum parameter level & \\
\hline
\end{tabular}

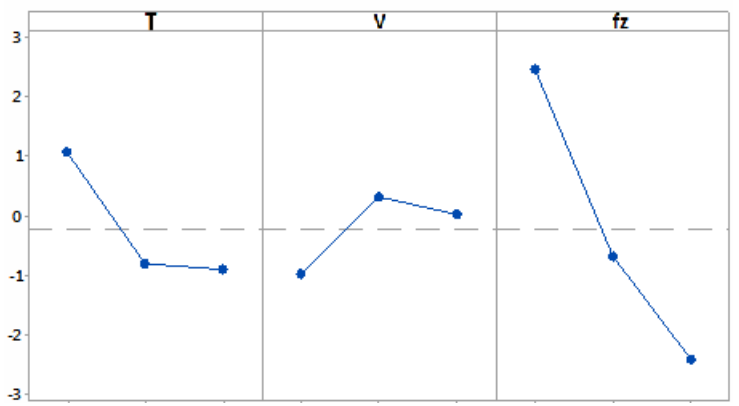

Figure 4. Main effect plot of Ra-Li against T-V-fz.
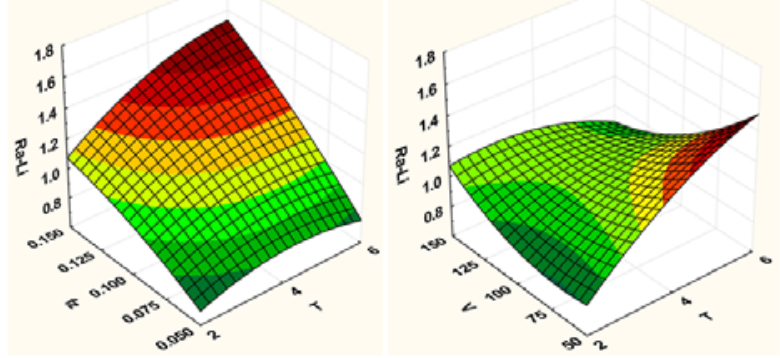

Figure 5. Surface plot of Ra-Li against T-fz and T-V

The transverse arithmetic average of the surface roughness values in vertical milling (Ra-Tv) are higher than longitudinal roughness (Ra-Lv) in almost in all cases. As depicted in surface plots Fig. $7(a, b)$ the minimum longitudinal arithmetic average of the surface roughness was achieved from 6 number of flute tool with minimum feed rate $(f=0.05 \mathrm{~mm} /$ teeth). It was clearly shown in Table 4 and in Fig. 7(a), the suitable machining 
parameters for minimum arithmetic average of the surface roughness are Number of flute Level 3 (6 Flute), cutting speed at Level $3(\mathrm{~V}=100)$ and feed rate (f) at Level $1(f=0.05)$. This experiment level (331) has not realized and it will be realized by confirmation experiment. As it can be seen from the Anova Table of S/N-Ra the feed per tooth is the major factor $(42.89 \%)$ affecting on the arithmetic average of the surface roughness.

Table 4. Response and Anova Table for Ra-Tv

\begin{tabular}{lcccc}
\hline \multicolumn{1}{c}{ Level } & $\mathbf{T}$ & $\mathbf{V}$ & $\mathbf{f z}$ & $\begin{array}{c}\text { Error / } \\
\text { Total }\end{array}$ \\
\hline $\mathbf{1}$ & -11.77 & -11.413 & $-7.34^{*}$ & \\
$\mathbf{2}$ & -10.81 & -10.18 & -10.48 & \\
$\mathbf{3}$ & $-7.50^{*}$ & $-8.49 *$ & -12.256 & \\
Delta & 4.26 & 2.9 & 4.91 & \\
Rank & 2 & 3 & 1 & \\
DF & 2 & 2 & 2 & $2 / 8$ \\
Seq SS & 3.93 & 1.25 & 4.56 & $0.88 / 10.6$ \\
MS & 1.96 & 0.62 & 2.28 & 0.44 \\
F-Value & 4.46 & 1.42 & 5.17 & \\
PCR\% & 36.9 & 11.81 & 42.89 & \\
R`2 $=91.7 \%^{\wedge}$ *: Optimum parameter level & & \\
\hline
\end{tabular}

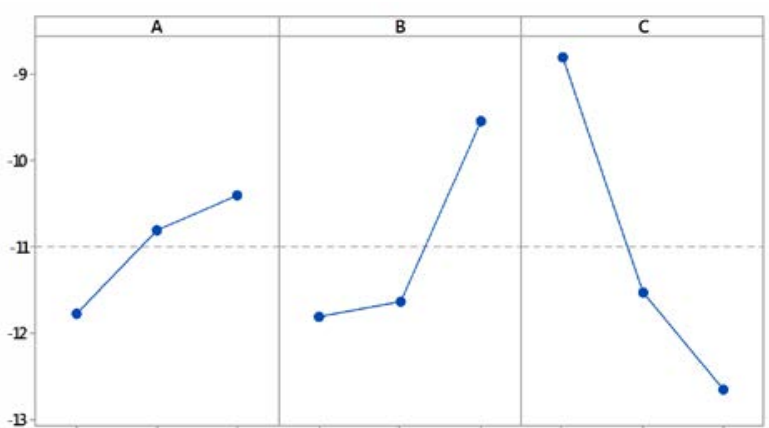

Figure 6. Main effect plot of Ra-Tv against T-V-fz.
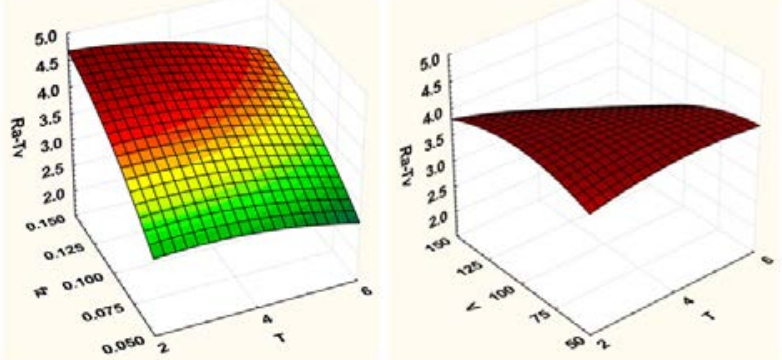

Figure 7. Surface plot of Ra-Tv against T-fz and T-V

Table 5 shows the response table, main effects plot and Anova results for calculated $\mathrm{S} / \mathrm{N}$ ratios of arithmetic average of the surface roughness for inclined milling along the transverse direction (RaTi). It can be derived from the Table 5 and Main effects plots (Fig 8.) that the greater influence on the transverse arithmetic average of the surface roughness is tool type (teeth number) followed by feed rate and cutting speed. The transverse arithmetic average of the surface roughness values in inclined milling (Ra-Ti) are higher than longitudinal roughness ( $\mathrm{Ra}-\mathrm{Li}$ ) and the transverse arithmetic average of the surface roughness values in inclined milling (Ra-Ti) are lower than vertical milling roughness ( $\mathrm{Ra}-\mathrm{Tv}$ ) in almost in all cases.

As depicted in surface plots Fig. $9(a, b)$ the minimum transverse arithmetic average of the surface roughness was achieved from 6 number of flute tool with minimum feed rate $(f=0.05$ $\mathrm{mm} /$ teeth) and maximum cutting speed. It was clearly shown in Table 5 and in Fig. 8, the suitable machining parameters for minimum arithmetic average of the surface roughness are Number of flute Level 3 (6 Flute), cutting speed at Level 3 $(\mathrm{V}=100)$ and feed rate (f) at Level $1(f=0.05)$. This experiment level (331) has not realized and it will be realized by confirmation experiment.

Table 5. Response and Anova Table for Ra-Ti

\begin{tabular}{ccccc}
\hline Level & $\mathbf{T}$ & $\mathbf{V}$ & $\mathbf{f z}$ & $\begin{array}{c}\text { Error / } \\
\text { Total }\end{array}$ \\
\hline $\mathbf{1}$ & -11.27 & -9.49 & $-5.70^{*}$ & \\
$\mathbf{2}$ & -6.96 & -8.55 & -7.87 & \\
$\mathbf{3}$ & $-5.75^{*}$ & $-5.93^{*}$ & -10.42 & \\
Delta & 5.52 & 3.56 & 4.72 & \\
Rank & 1 & 3 & 2 & \\
DF & 2 & 2 & 2 & $2 / 8$ \\
Seq SS & 4.45 & 0.95 & 2.13 & $0.011 / 7.7$ \\
MS & 2.22 & 0.47 & 1.15 & 0.005 \\
F-Value & 396.9 & 84.87 & 206.1 & \\
PCR\% & 57.6 & 12.31 & 29.91 & \\
R^2 = 99.85\% & $*$ : Optimum parameter level & \\
\hline
\end{tabular}

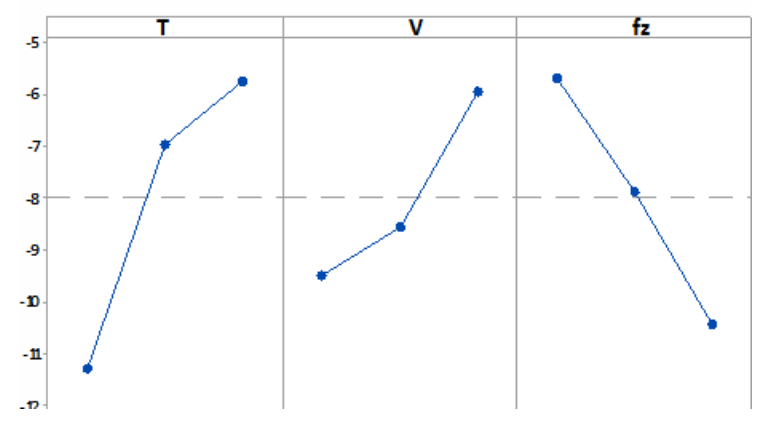

Figure 8. Main effect plot of Ra-Ti against T-V-fz.

Ahmad et al. found that transverse arithmetic average of the surface roughness is generally higher than the longitudinal arithmetic average of the surface roughness. They added that arithmetic 
average of the surface roughness in the longitudinal direction increased with an increase in feed rate and a decrease in spindle speed. And also authors reported that longitudinal surface roughness along tool movement direction is directly related to cutting parameters. But the transverse roughness is directly related tool geometry and then cutting parameters (Tsao, 2012). The similar result can be obtained from ANOVA table. As it can be seen from the Anova Table of S/N-Ra the flute number is the major factor (57.6\%) affecting on the arithmetic average of the surface roughness.
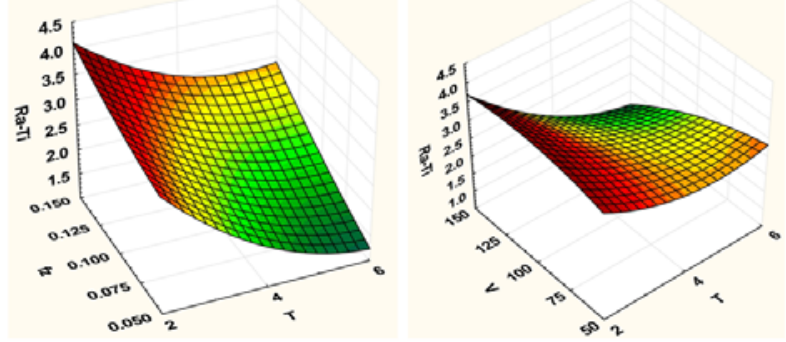

Figure 9. Main effect plot and surface plot of Ra-Ti against $T-f z$ and $T-V$

\subsection{Confirmation experiment}

The confirmation experiment is the final step of a design of experiment. Based on the $\mathrm{S} / \mathrm{N}$ ratios and ANOVA analyses, the optimal levels of all the control factors' combination were identified. As mentioned in the previous sections the optimum setting of parameters for machinability outputs are defined in the response tables. For this aim, the confirmation experiments were performed by conducting a test with optimal parameter value of the factors and levels evaluated by previous Taguchi analysis.

The one of the aim of confirmation tests is predict the outputs with the selected optimal machining parameters (Tsao 2012, Sunny et al. 2014, Gunay 2013). The procedure for $S / N$ ratio calculations from experimental data could be run reversely for determining the predicted value from $\mathrm{S} / \mathrm{N}$ ratio of optimal levels. For this aim the predicted optimal $\mathrm{S} / \mathrm{N}$ ratio using the optimal levels of parameters can be calculated with the following prediction equation; $\eta_{o p t}=\eta_{m}+\sum_{j=1}^{k}\left(\eta_{j}-\eta_{m}\right)$

where, $\eta_{\text {opt }}$ is the predicted optimal $\mathrm{S} / \mathrm{N}$ ratio, $k$ is the number of design factors and $\eta_{m}$ is the mean value of multiple $\mathrm{S} / \mathrm{N}$ ratios in all experimental runs, $\eta_{j}$ are the multiple $\mathrm{S} / \mathrm{N}$ ratios corresponding to optimum factor levels. If the $S / N$ is known and we want to learn about the expected result that will make the $S / N$. The procedure is to backtransform $\mathrm{S} / \mathrm{N}$ to find expected value and the prediction value can be calculated by help of Eq 1 . The optimal parameter levels, predicted and experimental output details for the machinability output were given in Table 6. Notice that the optimal parameter levels were indicated in response tables with superscript $(*)$ in previous sections. Confirmation experiments proved that the optimal levels predicted in the Taguchi analysis are reliable. The predicted and confirmation experiment output values are lower than the lowest value in the main experiments in almost all cases. The confirmation experiment reduced the results from 5.8 to $20.4 \%$ according to main experiments.

Table 6. Comparison of confirmation experiment results with the predicted values from Taguchi design

\begin{tabular}{|c|c|c|c|c|c|c|c|c|}
\hline \multirow{2}{*}{$\begin{array}{l}\text { Machina } \\
\text { bility } \\
\text { Output }\end{array}$} & \multicolumn{3}{|c|}{$\begin{array}{c}\text { Optimal } \\
\text { Level }\end{array}$} & \multirow{2}{*}{$\begin{array}{l}\text { Min. } \\
\text { Value } \\
\text { In main } \\
\text { experim } \\
\text { ents } \\
(\mu \mathrm{m})\end{array}$} & \multirow{2}{*}{$\begin{array}{l}\text { Confirm } \\
\text { ation } \\
\text { Exp. } \\
\text { Output } \\
(\mu \mathrm{m})\end{array}$} & \multirow{2}{*}{$\begin{array}{c}\text { Predic } \\
\text { ted } \\
\text { Value } \\
(\mu \mathrm{m})\end{array}$} & \multirow{2}{*}{$\begin{array}{l}\text { Relat } \\
\text { ive } \\
\text { Error } \\
(\%)\end{array}$} & \multirow{2}{*}{$\begin{array}{c}\text { Reduc } \\
\text { tion } \\
(\%)\end{array}$} \\
\hline & $T$ & V & $\begin{array}{l}f \\
z\end{array}$ & & & & & \\
\hline Ra-Lv & 1 & 3 & 1 & 0.95 & 0.81 & 0.783 & 3.33 & 14.73 \\
\hline Ra-Li & 1 & 2 & 1 & 0.69 & 0.65 & 0.612 & 5.8 & 5.81 \\
\hline Ra-Tv & 3 & 3 & 1 & 1.91 & 1.52 & 1.45 & 4.6 & 20.4 \\
\hline $\mathrm{Ra}-\mathrm{Ti}$ & 3 & 3 & 1 & 1.30 & 1.15 & 1.17 & 1.7 & 11.53 \\
\hline
\end{tabular}

\subsection{Deformation analysis}

Another focus point about machining of the fiber reinforced composites is the surface quality of the edges. It is essential to highlight here that due to the actions of machining forces, FRP composites exhibit a number of material damage or machining induced damage, which would not be normally observed during machining of metallic material. The parameters such as cutting speed, feed rate, tool material, tool geometry, fiber orientations and 
rake angles and type of machining such as conventional, climb milling and high speed milling have a great effect on the quality of the machine surface. The types of damage include delamination, sub-surface damage, fiber pull out, fiber bridging, spalling, and matrix cracking in machining of fiber reinforced composites. These damages have a great effect on surface quality and fatigue life of the components (Tsao 2008, Bhanacar 1995, Ramulu 2003).

Edge trimming of FRPC by peripheral milling generates Type I-II-III damage mechanism according to cutting parameters and fiber orientations. Type I Delamination is characterized as areas where plies have broken inwards. Type II delamination consists of uncut fibers protruding from the trimmed edges. The detached fibers from the trimmed surface along the tool movement direction are called as Type III delamination. Machining forces act in one direction and tend to lift the layers resulting in serious delamination (Ramulu 1991).

For determining the effect of cutting conditions on delamination the specimens are photographed and the delamination mechanisms were observed with macro scale. Cutting conditions and the images of the trimmed edges were given in Appendix-A1 in the appendix section. According the images it is observed that the vertical milling causes Type II delamination. The length and the density of the uncut fibers protruding from the trimmed edges were decreased in 6 flute cutting tools. The inclined mill caused the Type I-II delamination in the same time. A thick protruding and delaminated shell along the trimmed edges observed in inclined machining. The nearly clean and nearly sharp edges were observed in inclined machining with level 321. The increased number of teeth decreased the deformation on the edges although the increased number of teeth increases the feed of tool (Vf). Vf is the most effected parameter on machining time (Dilipak 2009).

\section{Conclusion}

The optimization of cutting parameter and edge trimming of CFRP composites has presented and discussed in this paper. The surface roughness and delamination behavior in vertical and inclined milling process for CFRP composites have been evaluated under different cutting conditions with various end mills. Based on the results the following conclusions can be drawn.

- The transverse arithmetic average of the surface roughness is higher than the longitudinal arithmetic average of the surface roughness in almost in all cases.

- The transverse and longitudinal arithmetic average of the surface roughness obtained by inclined machining is lower than vertical machining in all cutting conditions. It can be explained as; the chip removal can be realized easier and the cutting of fibers can be realized effectively by balanced cutting forces in inclined milling.

- For vertical machining; the minimum longitudinal arithmetic average of the surface roughness can be obtained with Number of flute Level 1 (2 Flute), cutting speed at Level $3(\mathrm{~V}=150)$ and feed rate $(f z)$ at Level $1(f z=0.05)$. The feed per tooth $(\mathrm{fz})$ is the most effective factor (40.6\%) affecting on the longitudinal arithmetic average of the surface roughness. The feed per tooth is the major factor (42.89\%) affecting on the transverse arithmetic average of the surface roughness in vertical milling.

- For inclined machining; the minimum transverse arithmetic average of the surface roughness was achieved with the suitable machining parameters as, number of flute Level 3 ( 6 Flute), cutting speed at Level $3(\mathrm{~V}=100)$ and feed rate $(f)$ at Level $1(\mathrm{f}=0.05)$.

- The longitudinal arithmetic average of the surface roughness values in inclined milling are lower than vertical milling in almost in all cases. The feed per tooth is the major factor (72.6\%) affecting on the longitudinal arithmetic average of the surface roughness inclined milling.

- The vertical milling causes Type II delamination. The length and the density of the uncut fibers protruding from the trimmed edges were decreased with increased number of teeth.

- The inclined mill caused the Type I-II delamination in the same time. The nearly clean and nearly sharp edges were observed in inclined machining with higher level of number of teeth and lower level of feed rate. The balanced forces 
along the tool axis by inclined milling decreased the delamination.

- Feed rate being the most prominent parameter effecting on the delamination. The increased number of teeth decreased the deformation on the edges although the increased number of teeth increases the feed of tool (Vf) which has a great effect on machining time.

\section{REFERENCES}

Ahmad, J,S., Nebu, U., Hossein, C., 2012. Machining Damage In Edge Trimming Of Cfrp. Materials And Manufacturing Processes, 27 (7) , 802-808.

Azmi, A.I., Lin, R.J.T., Bhattacharyya, D., 2013. Machinability Study Of Glass Fibre-Reinforced Polymer Composites During End Milling", International Journal of Advanced Manufacturing Technology, 64, 247-261.

Bhanacar, N., Ramakrishnann, N., Naik, K., Komanduri, R., 1995.On The Machining Of Fiber Reinforced Plastic (Frp) Composite Laminates. International Journal of Machine Tools \& Manufacture, 35(5), 701-716.

Dilipak, H., Güldaş A., Gezgin, A., 2009. An investigation of the effect of thenumber of inserts on the machining time and metal removal rate during the milling of AISI D3 steel at high cutting speeds. Strojniski Vestnik 55,7, 438-443.

Gunay, M., 2013.Optimization With Taguchi Method Of Cutting Parameters And Tool Nose Radius In Machining Of Aisi 3161 Steel. Journal Of The Faculty Of Engineering And Architecture Of Gazi University, 28(3),437-444.

Faraz, A., Dirk, B., Klaus, W., 2009. Cutting Edge Rounding: An Innovative Tool Wear Criterion In Drilling Cfrp Composite Laminates, International Journal of Machine Tools \& Manufacture, 49, 1185-1196.

Haddad, M., Zitoune,R., Bougherara, H., Eyma,F., Castanié, B., 2014.Study Of Trimming Damages Of Cfrp Structures In Function Of The Machining Processes And Their Impact On The Mechanical Behavior. Composites: Part B, 57, 136-143.

Haddad, M., 2014.Zitoune, R., Bougherara, H., Eyma, F., Castanié, B., "Study Of Trimming Damages Of Cfrp Structures In Function Of The Machining Processes And
Their Impact On The Mechanical Behavior", Composites: Part B, 57, 136-143.

Paulo, J., Davim, P.R., 2005. Damage And Dimensional Precision On Milling Carbon Fiber Reinforced Plastics Using Design Experiments. Journal of Materials Processing Technology, 160, 160-167.

Ramulua, M., Kima, D., Choib G., 2003. Frequency Analysis And Characterization In Orthogonal Cutting of Glass Fiber Reinforced Composites. Composites: Part A, 34, 949-962.

Rajamurugan, T.V., Shanmugam, K., Palanikumar, K., 2013.Analysis of Delamination In Drilling Glass Fiber Reinforced Polyester Composites. Materials And Design, 45, 80-87.

Sarıkaya, M., Yılmaz, V., Dilipak H., 2016. Modeling and multi-response optimization of milling characteristics based on Taguchi and gray relational analysis. Proceedings of the Institution of Mechanical Engineers, Part B: Journal of Engineering Manufacture, 230-6, 1049-1065.

Sunny, T., Babu J., Philip, J.P., 2014.Experimental Studies On Effect Of Process Parameters On Delamination In Drilling Gfrp Composites Using Taguchi Method. Procedia Materials Science, 6, 1131-1142.

Tsao, C.C., 2008.Thrust Force And Delamination Of CoreSaw Drill During Drilling Of Carbon Fiber Reinforced Plastics (Cfrp). International Journal of Advanced Manufacturing Technology, 37, 23-28.

Tsao, C.C., Chiu, Y.C., 2011. Evaluation Of Drilling Parameters On Thrust Force In Drilling Carbon Fiber Reinforced Plastic (Cfrp) Composite Laminates Using Compound Core-Special Drills. International Journal of Machine Tools \& Manufacture, 51(9), 740-744.

Tsao, C.C., 2012.Evaluation Of The Drilling-Induced Delamination Of Compound Core-Special Drills Using Response Surface Methodology Based On The Taguchi Method. International Journal of Advanced Manufacturing Technology, 62, 241-247. 
Appendix A1: Macro View of the trimmed edges of specimens, Milling Type and cutting conditions level

\begin{tabular}{|c|c|c|}
\hline Macro View of Trimmed Edges & Level & Mill Type \\
\hline$\mapsto 2 \mathrm{~mm}$ & 111 & $\mathrm{v}$ \\
\hline & 111 & I \\
\hline & 122 & v \\
\hline & 122 & 1 \\
\hline & 133 & v \\
\hline & 133 & 1 \\
\hline & 212 & v \\
\hline & 212 & 1 \\
\hline & 223 & v \\
\hline & 223 & 1 \\
\hline & 231 & v \\
\hline & 231 & 1 \\
\hline & 313 & v \\
\hline & 313 & I \\
\hline & 321 & v \\
\hline & 321 & 1 \\
\hline & 332 & v \\
\hline & 332 & I \\
\hline
\end{tabular}

